\title{
Design of an Antidumping Law
}

\author{
James C. Hartigan \\ University of Oklahoma
}

\begin{abstract}
The GATT/WTO requires an investigation documenting unfair pricing and material injury before AD duties can be imposed. Governments have discretion as to how many periods are included in the injury assessment and how long duties remain in effect. An AD law can be designed so that duopolists implement Markov Perfect rather than Nash-Bertrand strategies, affecting the equilibrium only in low demand states. Material injury doesn't occur, and no complaints are filed. This benefits the home firm and harms the foreign firm less than when duties are imposed. The home government also benefits when investigations and visible protection are costly.
\end{abstract}

- JEL Classification: F13

- Key Words: Dumping, Injury, Investigation, Unfair

\section{Introduction}

As is well known, the General Agreement on Tariffs and Trade/World Trade Organization (GATT/WTO) requires that an investigation establishing both the unfair pricing of exports and material injury to the home industry must be conducted for Antidumping (AD) duties to be sanctioned. Apart from mandating the investigation, the GATT/WTO permits considerable discretion by the investigating authority in implementing this requirement. This extends to what aspects of firm performance are emphasized, what time periods are utilized, and what comparisons are made between the foreign firm's export prices and the

*Corresponding Address: Department of Economics, University of Oklahoma, Norman, Oklahoma, USA 73019-2103, Email: hartigan@ou.edu. Phone: +405-325-5501, Fax: +405-325-5842.

*The author is at the University of Oklahoma and thanks the Australian National University for its supportive environment in facilitating the writing of part of this paper. 
prices it charges in the foreign market. It also extends to the clarity and consistency of the procedures implementing the requirement.

The present paper considers the optimal design of AD laws that conform to two stylized facts regarding the implementation of such laws. The first is that the material injury decision is dispositive. Under the U.S. implementation, firms are found guilty of unfair pricing about 95 percent of the time. Boltuck and Litan (1991) have documented biases on the part of the Department of Commerce (DoC) in making this decision. Australian Customs finds foreign firms culpable about 90 percent of the time. Thus, an affirmative material injury decision generally determines whether or not protection is awarded. The second is that the investigation of material injury examines a longer period of time than does the investigation of unfair pricing. To conform with the Uruguay Round, Congress directed the DoC, beginning in 1996, to use a full year of pricing data for the foreign firm. Prior to that, 6 months of data was common. However, the U.S. International Trade Commission typically collects home firm performance data for the preceding 3 years in conducting their material injury investigation. More formally, the foreign firm knows that the price it charges in period $t$ will affect the home firm's profitability in period $t .{ }^{1}$ Furthermore, it knows the home firm's profitability in periods $t$ through $t+\tilde{n}-1$ will be dispositive if the home firm files an AD complaint after $t+\tilde{n}-1$ periods, when $\tilde{n}$ of profits are examined in the material injury investigation. ${ }^{2}$ Thus, the manner in which the investigative authority implements the AD Code of the GATT/WTO creates a linkage between the foreign firm's current period price and the price it charges in subsequent periods. This is particularly important when there are fluctuations in the level of home market demand. The foreign firm's pricing over any $\tilde{n}$ periods is constrained by the home firm's profits, as it recognizes that it will be found guilty of unfair pricing with virtual certainty.

This paper deems these stylized facts to be the result of policy decisions and considers the optimal design of an AD law that emphasizes producer interests. Such an emphasis is consistent with the implementation of AD law. The U.S. and Australia do not have a national interest clause in their AD laws. The EC rarely

\footnotetext{
${ }^{1}$ DeVault (1993) found that profitability and market share were the economic criteria that best explain the material injury decision by the USITC.

${ }^{2}$ Ostensibly the unfairly traded imports should be disclosed as causing the material injury. However, a 3year horizon, such as utilized by the U.S., precludes any meaningful causality test. The present paper focuses solely on material injury. It is not concerned with a causality test, as it takes an affirmative dumping verdict as a given. This is consistent with the U.S. and Australian implementation of the law.
} 
invokes theirs. In designing the law, it is supposed that protection of a government's constituent firms occurs at a cost when it does so visibly. Thus it prefers to alter the firm's strategic behavior without the $\mathrm{AD}$ investigative process being invoked. The policy instruments by which the law is designed include the number of periods in which the AD duty is in effect, the number of periods over which the petitioning firm's profits are examined, and the level of the AD duty.

Consideration of the design of the $\mathrm{AD}$ law is the contribution of the paper. ${ }^{3}$ However, it is related to three literatures. The first is the demonstration by Hartigan (1995), Messerlin (1990), Prusa (1992), and Staiger and Wolak (1992) that an AD law may promote collusion. ${ }^{4}$ The second is the disclosure by Finger (1981), Herander and Schwartz (1984), Leidy and Hoekman (1991), Salvatore (1989), and Staiger and Wolak (1992) that an AD law may be used to induce less aggressive pricing by foreign firms. That is, the threat of an AD complaint intimidates foreign firms into charging higher export prices to avoid the costly $\mathrm{AD}$ investigation. The third is the endogenous protection literature of Fischer (1992), Leidy (1994), and Prusa (1994). These papers consider endogenous outcomes of $A D$ investigations in which firms know the probability distribution for the imposition of $\mathrm{AD}$ duties in any equilibrium and take these into account in their strategic optimization..$^{5}$ These models suggest that both home and foreign duopolists will play less aggressively in the first period of a two period model. The home firm attempts to induce $\mathrm{AD}$ duties, while the foreign firm attempts to circumvent them. A contrast in the present paper is that the foreign firm attempts to preclude injury to the home firm, acknowledging that it will always be found guilty of unfair pricing. Another difference is that, in the present paper, the design of the $\mathrm{AD}$ law removes any ambiguity regarding the outcome in any state of home demand. A contrast with the collusion literature is that the home AD law may not benefit the foreign firm. A distinction with regard to the literature on less aggressive pricing is the focus on the design of the AD law and the concomitant implication that it is not necessary to periodically file to harass the foreign firm.

\footnotetext{
${ }^{3}$ There has been little consideration given to the design of $\mathrm{AD}$ policy in the literature. Typically, the GATT/WTO AD Code is taken as given. An exception is Bian and Gaudet (1997) which considered the optimal level of $\mathrm{AD}$ duties in a two-government/two-firm game.

${ }^{4} \mathrm{~A}$ counter example in which an AD law enhances competition is provided by Hartigan (2000).

${ }^{5}$ In contrast to the present paper, these are finite (2-period) horizon models. They also suppose that the foreign firm tries to avoid an affirmative unfair pricing verdict. The present paper takes the unfair pricing verdict as a certainty and assumes that the foreign firm seeks to avoid an affirmative material injury decision. It also does not require any direct relationship between imports and injury.
} 
The present paper portrays a differentiated products, infinite horizon, NashBertrand duopoly sans an AD law. Subsequently, an AD law is introduced. When the demand realization is high, the equilibrium is identical to that of a NashBertrand stage game with differentiated products and costless renegotiation of collusion. ${ }^{6}$ When the demand realization is low, the foreign firm averts the AD complaint by charging a higher price than that of the stage game. This is not collusive, as the firms are not acting cooperatively. Neither is it harassment, as petitions are not, in equilibrium, filed by home firms. The structure of the investigation is common knowledge, and the foreign firm is able to circumvent the AD process by taking into account how the investigations are conducted. ${ }^{7}$ The home government is assumed to be able to accurately assess the demand and cost functions of the firms through its investigation. ${ }^{8}$ Because the law utilizes a longer material injury horizon than an unfair pricing horizon, and the injury decision is dispositive, the $\mathrm{AD}$ law will establish a linkage between periods in the foreign firm's pricing decision. That is, the appropriate equilibrium concept will be converted from Nash-Bertrand to Markov Perfect. A conclusion follows the discussion of free trade and the AD law.

\section{Free Trade}

A home and a foreign firm with identical and constant marginal costs produce a differentiated product for sale in the home market. There are no fixed costs. The foreign market is deemed irrelevant to the analysis because of the well documented biases in calculating the dumping margin. The firms play an infinite horizon game of strategic complements. That is the horizon is $\mathrm{T}: \mathrm{T} \rightarrow \infty$. As Hartigan (2000) and McCutcheon (1997) have disclosed, a duopoly in which the costs of renegotiating collusion are less than the costs of implementing punishment for protection will not generate collusion. In such a circumstance, firms will always defect because they (correctly) believe that punishment will never occur. That is, punishments are not credible if there is a lower cost

\footnotetext{
${ }^{6}$ McCutcheon (1997) and Hartigan (2000) have disclosed that collusion in a duopoly will not be manifest if the costs of renegotiation of collusion are low. Thus, we invoke an infinite horizon without regard to the Folk Theorem.

${ }^{7}$ Unlike harassment, no petitions need ever be filedby the home industry if the foreigners know the sturcture of the home government's AD law. That is, they know the criteria by which the decisions are made when the game begins. These criteria may be codified in the AD statute.

${ }^{8}$ For a discussion trade policy with uninformed policy makers, see Herander and Kamp (1999).
} 
(renegotiation) means of responding to defection. So that there will be no intertemporal linkage in the duopolists' strategic optimization decisions in free trade, such an assumption is invoked here. That is, there is no collusion in free trade.

The common discount factor is $\delta: 0<\delta<1$. The home (foreign) duopolist is denoted by $h(\mathrm{f})$. There are two realizations in demand in each period $t=[0, \mathrm{~T})$. These are $\alpha_{t} \in\left\{\alpha^{L}, \alpha^{H}\right\}$, where $\alpha^{H}>\alpha^{L}$ in $\mathrm{R}+$. The density function for the demand realization in each period $t$ is given by $g\left(\alpha_{t}\right)$, where $g\left(\alpha^{L}\right)+g\left(\alpha^{H}\right)=1$. The realization of $\alpha_{t}$ denotes the intercept of the demand function. The density function can be utilized to obtain an expected level of demand in each period $t$. This is indicated by $\alpha_{t}$. Demand is trendless, so that $d \bar{\alpha}_{t} /(d t)=0$. The firms know the realization of when they choose their price $\rho_{t}^{i}, i=h, f$ in each period $t$. Demand realizations in each period are independently and identically distributed. Each firm's stage game profits can now be expressed as

$$
\pi_{t}^{i}=\pi_{t}^{i}\left(\alpha_{t} ; p_{t}^{h}, p_{t}^{f}\right), i=h, f
$$

These profit functions are continuous and concave in their own prices, given the rival firm's price. This ensures that the best response mappings are functions. Differentiating the $\pi_{t}^{i}$ with respect to $p_{t}^{i}$ and setting the result equal to zero yields a pair of first order conditions. These are manipulated to give a pair of best response functions

$$
p_{t}^{i}=b_{t}^{i}\left(\alpha_{t} ; p_{t}^{j}\right) ; i, j=f, h \text { and } i \neq j .
$$

These are solved for the market equilibrium in each period $t$. This is given by the triple $\left(\alpha_{t}, p_{t}^{f^{*}}\left(\alpha_{t}\right), p_{t}^{h^{*}}\left(\alpha_{t}\right)\right)$. Note that $\partial p_{t}^{i} / \partial \alpha_{t}>0$, as a higher realization of home demand induces higher prices. Since this is a model of strategic complements, $\partial p_{t}^{j} / \partial p_{t}^{i}>0$, for duopoly prices that are below the price that a monopolist would charge.

Profits for each firm are obtained by substituting the equilibrium prices and the demand realization into (1). This yields $\pi_{t}^{i *}\left(a_{t}\right), \forall=f, h$.

So that the duopoly remains a viable market structure, the restrictions

$$
\pi_{t}^{i^{*}}\left(\alpha^{L} ; p_{t}^{i^{*}}, p_{t}^{j^{*}}\right) g\left(\alpha^{L}\right)+\pi_{t}^{i^{*}}\left(\alpha^{H} ; p_{t}^{i^{*}}, p_{t}^{j^{*}}\right)\left(1-g\left(\alpha^{L}\right)\right) \geq 0,
$$

are imposed. Equation (3) indicates that expected profits in each period are nonnegative. That is, before the level of demand is realized, the firms expect to earn nonnegative profits through participation in the home market. So that the 
market equilibrium is stable, the restriction

$$
\partial^{2} \pi_{t}^{i}\left(a_{t} ; p_{t}^{i}, b_{t}^{j}\left(\alpha_{t} ; p_{t}^{i}\right)\right) / \partial p_{t}^{i} \partial p_{t}^{j}<-\partial^{2} \pi_{t}^{i} / \partial p_{t}^{i^{2}} \forall p_{t}^{j}
$$

is also imposed. This ensures the uniqueness of the equilibrium price in each period. Thus, we can state that $0<\partial b_{t}^{i} / \partial p_{t}^{j}<1 \forall p_{t}^{j}$, implying product differentiation.

As the model indicates, the firms' choice of their optimal price in any period $t$ is independent of its optimal price in period $t-1$, as well as any forecast it might make of its optimal price in period $t+1$. This is because the low costs of renegotiating collusion results in collusion never taking place. As the next section discloses, the introduction of an $\mathrm{AD}$ law that is implemented according to the procedure commonly followed under the AD Code dramatically alters this independence.

\section{An Antidumping Law}

The material injury investigation begins after receipt of a petition by the home industry. It covers the preceding $\tilde{n}$ periods and takes place between periods. That is, the material injury investigation after period $t$ examines the home firm's profitability in periods $t-\tilde{n}+1$ through $t$, but the simultaneous investigation of the unfair act evaluates the foreign firm's pricing in period $t$. Furthermore, the foreign firm is culpable of dumping with virtual certainty. Let the expected level of home market profits in period t be given by $\bar{\pi}_{t}^{-h}$. This is obtained from (3).

It is extremely difficult to establish causality between imports and home industry performance with 3 years of data. I will suppose that the investigative authority finds in the affirmative regarding material injury whenever the home firm's profits over a $\tilde{n}$ period investigation horizon are $^{9}$

$$
\sum_{i=t}^{t+\tilde{n}-1} \pi_{i}^{h^{*}}\left(\alpha_{i}\right)<\sum_{i=t}^{t+\tilde{n}-1} \bar{\pi}_{i}
$$

I will suppose, that as part of the AD law, the authority chooses the AD duty so that the home firm earns the expected level of profits in the low demand state:

\footnotetext{
${ }^{9}$ Kelley and Morkre (1997), using a computable partial equilibrium model, disclose that an affirmative U.S. ITC decision does not require a significant effect of imports on firm performance. The implication is that the profitability of the firm is what matters.
} 


$$
\pi_{t}^{h *}\left(\alpha^{L}, d\right)=\stackrel{-h}{\pi_{t}},
$$

where $d$ indicates the AD duty. Both firms can correctly anticipate the level of the $\mathrm{AD}$ duty that will be imposed when the home firm is deemed materially injured. They know the level of home firm profits that will induce an affirmative injury verdict. They also know the $\tilde{\mathrm{n}}$ period horizon for the injury decision and the one period horizon for the unfair act determination. Furthermore, they know the expected level of demand in each future period. This is because they are aware that demand is trendless, and know the probability distribution over demand realizations. The home firm benefits from the $\mathrm{AD}$ duty when $\alpha_{t}=\alpha^{H}$, so that $\pi_{t}^{h^{*}}\left(\alpha^{H}, d\right)>\pi_{t}^{h^{*}}\left(\alpha^{H}\right)$. Thus, its expected gain from the duty in each period is $\bar{\pi}_{t}^{h^{*}}(d)-\bar{\pi}_{t}$.

\section{A. The Foreign Firm}

The foreign firm is harmed by the duty under either realization of home demand. Its expected profits in free trade are given by (3). Let us denote its expected profits with the duty as $\bar{\pi}_{t}^{f}(d)$. The cost to the foreign firm for having the duty in place for one period is the difference in its expected profits under the free trade and duty restricted scenarios: $\frac{-f}{\pi_{t}}-\frac{-f}{\pi}(d)$. Let us suppose that the duty remains in place for $n$ periods. ${ }^{10}$

By taking into account the home government's material injury criteria, the foreign firm can select a price that permits the home firm to realize profits of $\bar{\pi}_{t}^{h}$ when $\alpha_{t}=\alpha^{L}$ when $\alpha_{t}=\alpha^{H}$, there is no contribution to material injury. Let $\tilde{\pi}_{t}^{f}\left(\alpha^{L}\right)$ be the foreign firm's profits when it prices to preclude home injury in the low demand realizations. Recall also that a $\tilde{n}$ period horizon is utilized by the investigative authority to ascertain material injury. Let us suppose that this horizon is a policy decision, as is the number of periods for which a duty remains in place. Thus, the effect of pricing in period t to circumvent the duty in periods $t+\tilde{n}$ to $t+\tilde{n}+n-1$ given that $\alpha_{t}=\alpha^{L}$, is

$$
\begin{gathered}
\tilde{\pi}_{t}^{f}\left(\alpha^{L}\right)-\pi_{t}^{f^{*}}\left(\alpha^{L}\right)+\sum_{i=t+1}^{t+\tilde{n}-1} \delta^{i-t} g\left(\alpha^{L}\right)^{i-t}\left[\tilde{\pi}_{i}^{f}\left(\alpha^{L}\right)-\pi_{i}^{f^{*}}\left(\alpha^{L}\right)\right] \\
+\sum_{i=t+\tilde{n}}^{t+n+\tilde{n}-1} \delta^{i-t}\left[\bar{\pi}_{i}^{f}-\bar{\pi}_{i}^{f^{*}}(d)\right] \stackrel{\geq}{<} 0
\end{gathered}
$$

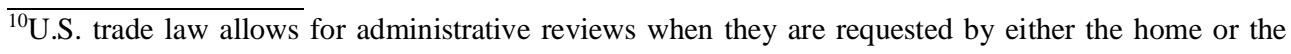
foreign firm. Typically, duties remain in place for at least a year before any review is granted. 
The expression in (7) is concave in $n$ and $\tilde{n}$ because $\delta, g<1$. Clearly, the effect in periods $t+\tilde{n}$ through $t+\tilde{n}+n-1$ is positive, since the duty is avoided. Increasing $n$, for a given $\tilde{n}$, raises the value of pricing to avoid material injury to the home firm. The effect of an increase in $\tilde{n}$ on (7) is ambiguous. Since the foreign firm must charge a higher price than in the static NB equilibrium to preclude injury to the home firm, and the game is one of strategic complements, both firms will charge higher prices. As Appendix I indicates, this will benefit the foreign firm if the resulting equilibrium is close to that of free trade. Otherwise, the foreign firm will lose relative to the static NB equilibrium. If all three terms in (7) are positive, the foreign firm will prefer to set a price during low demand realizations that precludes material injury to the home firm. However, if the first two terms are negative, then the $\tilde{n}$ periods of profit sacrifice may or may not justify avoiding the future $\mathrm{AD}$ duty. The greater is $\tilde{n}$, or the longer the horizon the investigative authority utilizes to ascertain injury, the less incentive the foreign firm will have to preclude injury to the home firm for a given value of $n$ when avoidance is costly. Thus $n$ and $\tilde{n}$ jointly determine the foreign firm's pricing incentives in the presence of a home AD law.

\section{B. The Home Firm}

Now let us consider how the home AD law affects the incentives of the home firm. If $\alpha_{t}=\alpha^{L}$, material injury occurs. If $\alpha_{t}=\alpha^{H}$ it does not. The home firm obtains a future benefit from manipulating its performance to obtain a duty in the subsequent $n$ periods irrespective of the demand realizations. It can induce an affirmative material injury verdict in period $t$ if it sacrifices profits when the demand realization is high. This requires earning $\pi_{t}^{h^{*}}\left(\alpha^{H}\right)-\varepsilon, \varepsilon>0$ so that expected profits become $\bar{\pi}_{t}^{h}-\varepsilon$. ${ }^{11}$ The expected gain from this duty in $t+\tilde{n}$ is $\bar{\pi}_{t+\tilde{n}}^{h}(d), \quad>\bar{\pi}_{t+\tilde{n}}^{h}$. Recall that a $\tilde{n}$ period horizon is utilized by the investigative authority to ascertain material injury. Let us suppose that this horizon is a policy decision, as is the number of periods for which the duty remains in place. For the home firm to set a price in period $t$ in which high demand is realized, so that spurious injury occurs requires

$$
\pi_{t}^{h^{*}}\left(\alpha^{H}\right)-\bar{\pi}_{t}^{h}-\varepsilon+\sum_{i=t+1}^{t+\tilde{n}-1} \delta^{i-1} g\left(\alpha^{H}\right)^{i-t}\left[\pi_{i}^{h^{*}}\left(\alpha^{H}\right)-\pi_{t}^{h^{*}}-\varepsilon\right]
$$

\footnotetext{
${ }^{11}$ Recall the injury standard given by (5).
} 
Figure 1. Investigan Time Line

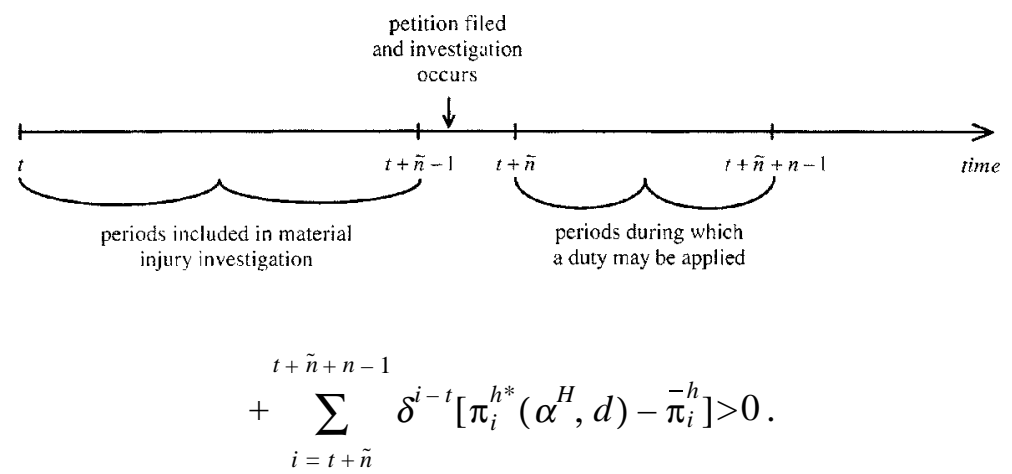

Since $\delta, g<1$, the expression in (8) is concave in $n$ and $\tilde{n}$. The third term in (8) must be positive, as it represents the $n$ periods of competition in which the foreign firm is encumbered by the duty. The first two terms, however, are negative, as they denote the $\tilde{n}$ periods of competition during which the home firm is sacrificing current and expected future profits so as to (spuriously) establish material injury. The greater is $\tilde{n}$, the less incentive the home firm has to feign injury for a given $n$. The larger is $n$, the greater the incentive of the home firm to appear to be injured for a given $\tilde{n}$. As was the case for the foreign firm, $n$ and $\tilde{n}$ jointly determine the home firm's pricing incentives when the home government has enacted an AD law. The time line for the material injury investigation and the duty is given in Figure 1.

Although the GATT/WTO does require a country to use a year of pricing data to establish the existence of an unfair act, a country has discretion as to the length of $n$ and $\tilde{n}$. Thus, the policy choices available to the home government in its formulation of its $\mathrm{AD}$ law are $n$ and $\tilde{n}$ and how the duty is calculated. Increasing $\tilde{n}$ reduces the incentive for the home firm to claim spurious injury. However, it raises the incentive of the foreign firm to ignore the material injury criteria (5), as the $\mathrm{AD}$ duty is pushed further into the future. Increasing $n$ raises the incentive of the foreign firm to abide by the injury criterion. However, it also raises the incentive of the home firm to claim spurious injury.

\section{An Equilibrium}

\section{A. The Duopolists}

Let $n^{*}$ be the smallest integer value at which (7) is positive, and $\tilde{n}^{*}$ is the 
smallest integer value at which (8) is negative. If such a pair exist, the home government can mitigate competition without an AD complaint being filed. In this circumstance, the home firm's optimization problem is identical to that of (1). However, the foreign firm's problem becomes

$$
\Pi_{t}^{f}\left(\alpha_{t}\right)={ }_{p_{t}^{f}}^{M A X} \pi_{t}^{f}\left(\alpha_{t} ; p_{t}^{f}, p_{t}^{h}\right)+\delta \bar{\Pi}_{t+1}^{f}
$$

subject to (5).

Equation (9) is the Bellman equation. The first term on the right hand side is the immediate profit flow generated by the optimal price $p_{t}^{f^{*}}$. The second term is the continuation value, which is random from the perspective of period $t$. This expectation is formed using information available in period $t$. The expected level of foreign firm profits are obtained from $g(\cdot)$ and the possible realizations of $\alpha_{t}$. The constraint represents the injury standard of the investigative authority.

Given the simple framework, (9) is relatively easy to solve. When $\alpha_{t}=\alpha^{H}$ the constraint (5) is nonbinding. In this instance, the problem that the firms face is identical to that of free trade, which is given by (1). Hence the equilibrium is the triple $\left(\alpha^{H}, p_{t}^{f^{*}}\left(\alpha^{H}\right), p_{t}^{h^{*}}\left(\alpha^{H}\right)\right)$. That is, the home AD law does not affect the game between the firms in the high demand state.

The constraint does bind when $\alpha_{t}=\alpha^{L}$. The constraint, in essence, makes the foreign firm a von Stackelberg leader in the low demand state. That is, the equilibrium will be equivalent to one in which the foreign firm acts as a von Stackelberg leader subject to the constraint. ${ }^{12}$ The foreign firm calculates the home firm's best response function as in (2). It then determines the expected level of the home firm's profits from (3). We can also determine expected best response functions for the firms from $b_{t}^{i}\left(\alpha^{L} ; p_{t}^{j}\right), b_{t}^{i}\left(\alpha^{H} ; p_{t}^{j}\right)$ and $g\left(\alpha_{t}\right)$. These expected best responses functions $\bar{b}_{t}^{i}$ yield the pair $\left(\bar{p}_{t}^{h}, \bar{p}_{t}^{j}\right)$. They generate expected profits, which are termed $\bar{\pi}_{t}^{i}$. It locates the isoprofit curve on the home firm's best response function $b_{t}^{h}\left(\alpha^{L} ; p_{t}^{f}\right)$ that pertains to the expected level of home profits. The foreign firm then maximizes its profits by finding its isoprofit curve $\tilde{\pi}_{t}^{h}$ that

\footnotetext{
${ }^{12}$ This result is analogous to that of the single period profit shifting subsidy of Brander and Spencer (1985). That is, the equilibrium generated when the AD law shifts the best response function of the foreign firm is the same as the one that would emerge when the foreign firm was a von Stackelberg leader. That is, with the foreign firm subject to the home firm's profit constraint. In the present model, the foreign firm is maximizing profits in a dynamic framework generating a Markov Perfect Equilibrium.
} 
Figure 2. An Equilibrium with a Home AD Law

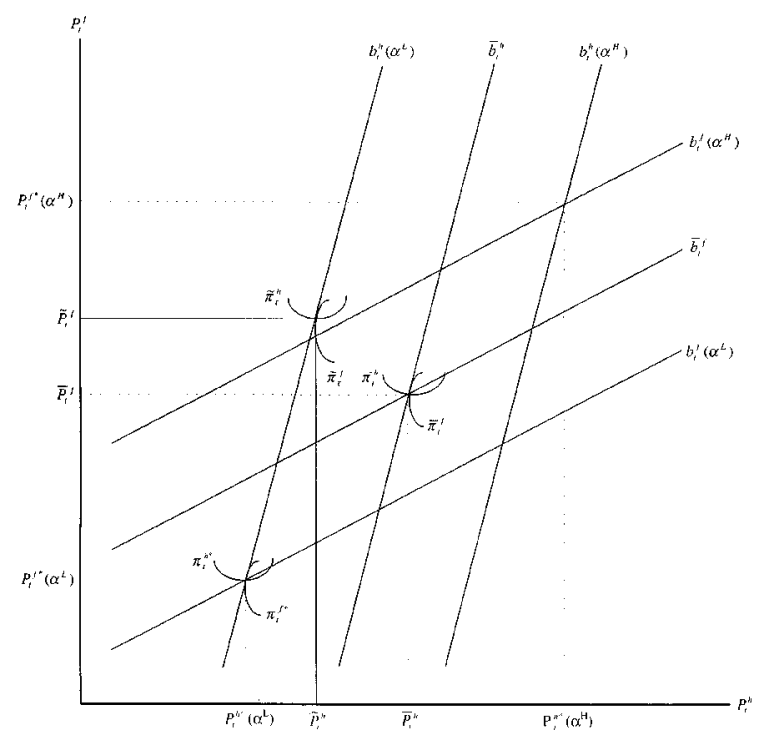

is tangent to $b_{t}^{h}\left(\alpha^{L} ; p_{t}^{f}\right)$ at the point where $b_{t}^{h}(\cdot)$ contains $\tilde{\pi}_{t}^{f}$. This corresponds to the isoprofit curve of $b_{t}^{h},\left(\alpha^{L}, p_{t}^{j}\right)$ at which the level of profits is equal to their expectation. This generates the pair $\left(\tilde{p}_{t}^{h}, \tilde{p}_{t}^{f}\right)$. The foreign firm selects the isoprofit curve that is tangent to $b_{t}^{h}(\cdot)$ at the point where the home firm's profit equals $\tilde{\pi}_{t}^{h}$ because this is the minimum level of home profits that precludes an affirmative material injury decision. The best that the foreign firm can do without reducing home firm profits below $\tilde{\pi}_{t}^{h}$ is $\tilde{\pi}_{t}^{f}$. An example is given in Figure 2.

Thus we can view the equilibrium in the low demand state as requiring that the foreign firm satisfy

$$
\bar{\pi}_{t}^{h}=\tilde{\pi}_{t}^{h}\left(\alpha^{L}\right)
$$

where $\tilde{\pi}_{t}^{h}\left(\alpha^{L}\right)$ is the home firm's profit level in the low demand realization at which (10) is binding. This yields the equilibrium $\left(\alpha^{L}, \tilde{p}_{t}^{f}\left(\alpha^{L}\right), \tilde{p}_{t}^{h}\left(\alpha^{L}\right)\right)$. Corresponding profit levels are $\tilde{\pi}_{t}^{h}\left(\alpha^{L}\right)$ and $\tilde{\pi}_{t}^{f}\left(\alpha^{L}\right)$. Together with the results for $\alpha_{t}=\alpha^{H}$, we have characterized the Markov Perfect Equilibrium.

To complete the characterization of the equilibrium, it must be determined if either firm has an incentive to block the other's deviation from the Nash stage game equilibrium. For example, does the home firm have an incentive to prevent the foreign firm from pricing to preclude injury when $\alpha_{t}=\alpha^{L}$ ? That is, by charging $\tilde{p}_{t}^{h^{*}}-\varepsilon$ Note that the home government is assumed to set $\mathrm{d}$ such that the home firm earns $-\bar{h}$ hen $\quad \alpha_{t}=\alpha$ Thus the home firm only gains from the duty 
when $\alpha_{t}=\alpha^{H}$. Deviation induces Nash-reversion, or the stage game Nash equilibrium, for each period. If (7) and (8) hold, the firms prefer to set prices that satisfy (10), or that preclude material injury from occurring.

\section{B. The Home Government}

Suppose that the home government's welfare is a function of its constituent duopolist's profits in each period, and the cost of conducting an investigation. The cost of the investigation includes payment to the factors of production utilized in conducting the investigation. It also includes the cost of drawing public attention to the awarding of protection to its import competing producers. For example, the government may want to espouse free trade rhetoric to exporters, consumers, and downstream producers. Granting $\mathrm{AD}$ duties to import competing producers undermines its policy credibility. Suppose, then, that the government prefers to award protection without attracting attention.

The policy instruments available to the government include how it calculates the $\mathrm{AD}$ duty $\mathrm{d}$, the number of periods the $\mathrm{AD}$ duty remains in affect $n$, and the number of periods over which material injury must be established $\tilde{n}$. Although the GATT/WTO does impose some constraints as to the calculation of the duty, such as requiring that at least a year of pricing data be used, the investigative authority has considerable discretion in this regard. This extends to the use of constructed values in the calculation of a normal foreign market price, and the decision as to whether the duty should be set to eliminate injury, as is the EC's practice, or whether it should be the difference between foreign market price and the export price. Under the AD Code of the GATT/WTO, governments have considerable latitude in the setting of $n$ and $\tilde{n}$. In the U.S., for example, either the home or foreign firm can request a review of the duties, but they typically remain in place for at least a year.

Suppose that the government's expected welfare function in any period $t$ is given by

$$
W_{t}=\pi_{t}^{h}-c_{t}
$$

where $c_{t}$ is the cost of imposing duties in that period. It is assumed that $c_{t}=0$ if the $\mathrm{AD}$ law is designed so that firms modify their prices without a home complaint being filed. That is, the protection is invisible. Suppose also that $c_{t}$ is higher in a period in which an investigation is conducted than when one is not in process.

If the government can raise its per period welfare without a complaint being 
filed through appropriate choices of $\mathrm{d}, n^{*}$, and $\tilde{n}^{*}$, it will clearly prefer this outcome to one with the same increase in its constituent duopolist's profits with $c_{t}>0$. That is, it is presumed that $n$ and $\tilde{n}$ exist to satisfy (7) and (8). The design of the AD law will, of course, depend upon the government's objective, which is exogenous to this model. It is assumed that the government does not want the home firm's per period profits to fall below their expected level (in the absence of the law). It is implicit in the discussion that both firms are aware of the material injury criteria of the investigative authority of the home government and how the AD duty is calculated. Moreover, the paper also assumes, as is consistent with practice, that the injury decision is dispositive. That is, culpability for unfair pricing by the foreign firm is a virtual certainty. Thus transparency of the $\mathrm{AD}$ law and the investigative procedure are, in essence, part of the law's design.

\section{Conclusion}

When a government is primarily concerned with producer interests in the design and administration of its AD law, as appears to be the case with the principle invokers of the AD Code of the GATT/WTO, the law may be designed so that protection is largely invisible to nonproducers in the industry. The design of the $\mathrm{AD}$ law requires that the government choose the number of periods of low profits necessary to determine material injury, the number of periods that the duty will be in effect, and the level of the duty so that competition between home and foreign firms is mitigated. This requires that the AD law be credible, and be administered in a reasonably transparent manner. This differs from the endogenous protection literature in that both the home and the foreign firm know the outcome in each state of home demand. There is also no need for the home firm to harass the foreign firm with occasional filings of complaints. The design of the AD law can make it less onerous than when duties are implemented, in that the adverse consequences to consumers and downstream producers vanish when demand is high. Furthermore, if the design of the law induces a collusive outcome in which both firms benefit, as Appendix I indicates is possible, the detrimental effects also disappear when home demand is high.

Accepted January 11, 2000. 


\section{References}

Bian, Jiang, and Mitchell H. Kellman (1997), “Anti-dumping Laws and Oligopolistic Trade," Journal of Economic Integration 12, 62-86.

Boltuck, Richard, and Robert Litan (1991), Down in the Dumps, Brookings Institution, Washington, D.C.

Brander, James A., and Barbara J. Spencer (1985), "Export Subsidies and International Market Share Rivalry," Journal of International Economics 18, 83-100.

DeVault, James M. (1993), "Economics and the International Trade Commission," Southern Economic Journal 60,463-78.

Finger, J. Michael (1981), "The Industry-Country Incidence of Less than Fair Value Cases in the U.S. Import Trade," Quarterly Review of Economics and Business 21, 260-79.

Fischer, Ronald D. (1992), "Endogenous Probability of Protection and Firm Behavior," Journal of International Economics 32, 149-63.

Hartigan, James C. (1995), "Collusive Aspects of Cost Revelation Through Antidumping Complaints," Journal of Institutional and Theoretical Economics 151, 478-89.

Hartigan, James C. (2000), "An Antidumping Law Can Be Procompetitive," Pacific Economic Review 5, 5-14.

Herander, Mark G., and J. Brad Schwartz (1984), “An Empirical Test of the Impact of the Threat of U.S. Trade Policy: The Case of Antidumping Duties," Southern Economic Journal 51, 59-79.

Herander, Mark G., and Brad Kamp (1999), “Tariff Policy and Entry with Cost-Based Informational Asymmetries," Economic Inquiry 37, 60-73.

Kelly, Kenneth H., and Morris E. Morkre (1997), "Do Unfairly Traded Imports Injure Domestic Industries?" Review of International Economics 6, 321-32.

Leidy, Michael P. (1994), "Trade Policy and Indirect Rent Seeking: A Synthesis of Recent Work," Economics and Politics 6, 97-115.

Leidy, M., and B. Hoekman (1991), "Spurious Injury as Indirect Rent Seeking," Economics and Politics 3, 111-37.

McCutcheon, Barbara (1997), "Do Meetings in Smoke-Filled Rooms Facilitate Collusion?" Journal of Political Economy 105, 330-50.

Messerlin, Patrick (1990), "Antidumping Regulations or Procartel Law? The EC Chemical Case," World Economy 13, 465-92.

Prusa, Thomas J. (1992), “Why are so Many Antidumping Petitions Withdrawn?” Journal of International Economics 33, 1-20.

Prusa, Thomas J. (1994), "Pricing Behavior in the Presence of Antidumping Law," Journal of Economic Integration 9, 260-89.

Salvatore, D. (1989), "A Model of Dumping and Protectionism in the United States," Weltwirtschaftliches Archiv 125, 763-81.

Staiger, Robert W., and Frank A. Wolak (1992), “The Effect of Domestic Antidumping Law in the Presence of Foreign Monopoly," Journal of International Economics 32, 265-87. 


\section{Appendix}

Let us define the foreign firm's profits in a free trade NB equilibrium when $\alpha_{t}=\alpha^{L}$ as

$$
\pi_{t}^{f^{*}}\left(\alpha^{L} ; p_{t}^{f^{*}}, p_{t}^{h^{*}}\right) \equiv K
$$

Specify the function

$$
G\left(p_{t}^{f}\right)=\pi_{t}^{f}\left(\alpha^{L} ; p_{t}^{f}, p_{t}^{h}\right)-K
$$

Since $\partial^{2} \pi_{t}^{i^{*}} / \partial p_{t}^{f} \partial p_{t}^{h}>0$, both firms gain, relative to the NB equilibrium, from a small increase in prices. Because $\tilde{p}_{t}^{h}>p_{t}^{h^{*}}\left(\alpha^{L}\right), G^{\prime}=0, G^{\prime \prime}<0$ at a price $\hat{p}_{t}^{f}>p_{t}^{f^{*}}$. Since $b_{t}^{i^{\prime}}<1, \hat{p}_{t}^{f}<\tilde{p}_{t}^{h}$. However, $\tilde{p}_{t}^{f}>\tilde{p}_{t}^{h}$. Let

$$
d p_{t}^{f}=\tilde{p}_{t}^{f}-p_{t}^{f^{*}}
$$

Thus, $G^{\prime} d p_{t}^{f}$ is an approximation to the loss in the foreign firm's profits relative to the NB equilibrium from having to satisfy constraint (5). Since $G^{\prime}<0$ for $p_{t}^{f}>\hat{p}_{t}^{f}, d p_{t}^{f}$ must be small for the foreign firm to gain from the home AD law. Thus the equilibrium cannot deviate too much from free trade for the foreign firm to gain. 